\title{
PEMBERIAN TEPUNG TOMAT DAN AMPAS TAHU PADA PAKAN KOMERSIAL TERHADAP KUALITAS EKSTERNAL TELUR PUYUH (COTURNIX COTURNIX JAPONICA) PERIODE LAYER
}

\section{THE GIVING TOMATO FLOUR (LYCOPERSICON ESCULENTUM) AND TOFU WASTE ON COMMERCIAL FEED TO QUAIL TO EXTERNAL QUALITY OF QUAIL EGG (COTURNIX COTURNIX JAPONICA) LAYER PERIOD}

\author{
M Yusuf'a, D Kardaya, dan D Sudrajat
}

${ }_{1}^{1}$ Programstudi Peternakan Fakultas Pertanian Universitas Djuanda Bogor, Jl. Tol Ciawi No. 1, Kotak Pos 35 Ciawi, Bogor 16720.

aKorespondensi: Mochamad Yusuf, E-mail: feinatus@gmail.con

(Diterima oleh Dewan Redaksi: $\mathrm{xx}-\mathrm{xx}-\mathrm{xxxx}$ )

(Dipublikasikan oleh Dewan Redaksi: xx-xx-xxxx)

\begin{abstract}
Tomato (lycopersicon esculentum) is one of Indonesia's local fruits that contain lots of vitamin C and lycopene. Tofu waste is a plant commonly used as an alternative feed to reduce the cost of large feeds. The aims of this research is to find out how far the addition of tomato flour and tofu waste has an influence on the external quality of quail eggs (Coturnix coturnix japanica). The material used in this research was 160 quails, aged 35 weeks with the treatment given : P0 100\% control food; P1: 95\% control food $+2.5 \%$ tomato flour and $2.5 \%$ tofu waste; P2: $90 \%$ control food $+5 \%$ tomato flour and $5 \%$ tofu waste; P3: $85 \%$ control food $+7.5 \%$ tomato flour and $7.5 \%$ tofu waste. The design used was Completely Randomized Design (CRD) with 4 treatments and 3 replications with each treatment filled with 13 chickens so that there were 160 quails, then continued with Duncan's multiple range test. Variables observed during the study included egg index, shell thickness and egg weight. The results showed that giving tomato flour and tofu waste to quail feed did not affect the real results on the external quality of quail eggs (egg weight, shell thickness and egg index).
\end{abstract}

Key words : external quality of quail egg, tomato flour, tofu waste

\begin{abstract}
ABSTRAK
Tomat (lycopersicon esculentum) merupakan salah satu buah lokal Indonesia yang banyak mengandung banyak vitamin $\mathrm{C}$ dan lycopene. Ampas tahu merupakan tanaman yang biasa digunakan sebagai pakan alternatif untuk mengurangi biaya pakan yang besar. Penelitian ini betujuan untuk mengetahui sejauh mana penambahan tepung tomat dan ampas tahu memberikan pengaruh terhadap kualitas eksternal telur burung puyuh (Coturnix coturnix japanica). Materi yang digunakan dalam penelitian ini adalah 160 ekor burung puyuh berumur 35 minggu dengan perlakuan yang diberikan yaitu P0 : $100 \%$ pakan kontrol ; P1: pakan kontrol 95\% + 2,5\% tepung tomat dan 2,5\% ampas tahu; P2: pakan kontrol 90\% + 5\% tepung tomat dan 5\% ampas tahu; P3: pakan kontrol 85\% + tepung tomat 7,5\% dan 7,5\% ampas tahu. Rancangan yang digunakan adalah Rancangan Acak Lengkap (RAL) dengan 4 perlakuan dan 3 ulangan dengan masing-masing perlakuan diisi dengan 13 ekor ayam sehingga terdapat 160 ekor burung puyuh, kemudian dilanjutkan dengan uji jarak berganda Duncan. Variabel yang diamati selama penelitian meliputi indeks telur, tebal kerabang dan bobot telur. Hasil penelitian menunjukan pemberian tepung tomat dan ampas tahu pada pakan burung puyuh tidak mempengaruhi hasil yang nyata pada kualitas eksternal telur burung puyuh (bobot telur, tebal kerabang dan indeks telur).
\end{abstract}

Kata kunci : kualitas eksternal telur puyuh, tepung tomat, ampas tahu 
M Yusuf, D Kardaya, dan D Sudrajat. 2019. Pemberian Tepung Tomat dan Ampas Tahu pada Pakan Komersial Terhadap Kualitas Eksternal Telur Puyuh (Coturnix coturnix japonica) Periode Layer. Jurnal Peternakan Nusantara $5(1)$ : 51-56.

\section{PENDAHULUAN}

Burung puyuh merupakan salah satu ternak yang mudah dibudidayakan dan memiliki keunggulan yaitu produksi telur, daging dan masa pemeliharaan yang singkat dan mudah. Puyuh yang sudah produktif mampu menghasilkan telur mencapai 250-300 butir/tahun dengan berat rata-rata $10 \mathrm{~g} /$ butir. Burung puyuh betina mulai bertelur pada umur 42 hari dengan puncak produksi mencapai $76 \%$ pada umur 5 bulan (Nasution, 2007). Keistimewaan lain burung puyuh yaitu mempunyai siklus hidup yang pendek, tubuh kecil sehingga tidak memerlukan tempat yang luas.

Peningkatan potensi produksi telur puyuh selain dipengaruhi oleh faktor genetik juga dipengaruhi lingkungan. Secara genetik produksi telur pada puyuh sangat tinggi tetapi sifat ini tidak akan tercapai apabila faktor lingkungan tidak menunjang. Salah satu faktor lingkungan yang penting adalah pemberian ransum. Ransum yang baik ialah yang mempunyai nilai gizi seimbang, tepat dan mengandung protein, lemak, karbohindrat, vitamin dan mineral (Widodo 2002). Pakan merupakan komponen terbesar dari biaya produksi yaitu sekitar 70-80\%. Pencarian pakan alternatif sebagai pengganti sumber pakan merupakan upaya peternak untuk meminimalkan biaya pakan. Hal ini dapat dilakukan dengan memanfaatkan bahan-bahan yang kurang bermanfaat atau hasil samping suatu produk, tersedia dalam jumlah banyak, mudah diperoleh, harganya murah dan mempunyai nilai nutrisi. Oleh karena itu, perlu pakan alternatif untuk mengatasi salah satunya yaitu dengan memanfaatkan campuran tepung tomat dan ampas tahu.

Pemanfaatan tomat sebagai bahan pakan ternak dapat dilakukan sebagai upaya peningkatan produktifitas ternak. Tomat berpotensi sebagai bahan pakan sumber vitamin, mineral dan antioksidan yang murah. Mappiratu et al (2010) menyatakan bahwa tomat mengandung vitamin $\mathrm{C}$, vitamin $\mathrm{B}$, vitamin $\mathrm{E}$ dan provitamin A. Sedangkan mineral meliputi $\mathrm{Ca}, \mathrm{Mg}, \mathrm{P}, \mathrm{K}, \mathrm{Na}, \mathrm{Fe}$, sulfur dan klorin. Tomat juga mengandung senyawa seperti solanin, saponin, asam folat, asam malat, asam sitrat, bioflavonoid (termasuk lycopene, alfa dan beta-karoten), protein, lemak dan histamine. Lycopene merupakan salah satu senyawa yang paling banyak dalam tomat. Sumardiono et al (2008) melaporkan kandungan lycopene pada buah tomat segar sebesar $6,6 \mathrm{mg} / 100 \mathrm{~g}$ senyawa ini berguna sebagai antioksidan. Dengan diberikannya likopen dalam ransum pakan pada burung puyuh diharapkan dapat meningkat dan kualitas telur lebih baik. Ampas tahu adalah salah satu bahan yang dapat digunakan sebagai sumber protein, bahan pakan ini mengandung protein $8,66 \%$; lemak $3,79 \%$; air $51,63 \%$ dan abu 1,21\%. Namun protein yang tinggi tidak akan berpengaruh banyak terhadap kualitas telur jika tidak diimbangi dengan konsumsi yang baik. Dalam hal ini, buah tomat mampu melengkapi ampas tahu sebagai campuran dalam pakan komersial.

Tujuan dari penelitian ini yaitu untuk mengetahui pengaruh pemberian tepung tomat dan ampas tahu dalam pakan komersial terhadap kualitas eksternal telur burung puyuh (Coturnix coturnix japonica). Hipotesis penelitian ini adalah penambahan tepung tomat dan ampas tahu dalam pakan pada puyuh periode produksi (Coturnix coturnix japonica) berpengaruh terhadap kualitas eksternal telur burung puyuh. Penelitian ini diharapkan dapat bermanfaat untuk menghasilkan puyuh petelur yang berproduksi lebih baik dengan penambahan tepung tomat dan ampas tahu dalam pakan komersial.

\section{MATERI DAN METODE}

\section{Materi}

Penelitian ini dilaksanakan di peternakan puyuh CV Kayumanis Quail Farm yang berada di Jalan Gg Masjid Al-Makmury RT 02 RW 02 nomor 8 Kelurahan Kencana, Kecamatan Tanah Sareal, Kota Bogor, Jawa Barat. Penelitian ini berlangsung selama empat minggu, di mulai pada bulan Mei sampai bulan Juni 2018. 
Peralatan yang digunakan saat pemeliharaan di lapang adalah kandang sistem baterai bertingkat empat sebanyak 3 unit dengan ukuran sangkar layer yaitu 100 x 60 x $177 \mathrm{~cm}$ dengan kemiringan alas sangkar $5 \mathrm{~cm}$. Peralatan lain yang digunakan dalam pemeliharaan layer yaitu tempat pakan berukuran $100 \times 7 \times 6 \mathrm{~cm}$, tempat minum berkapasitas, egg tray, serta alat penunjang kebersihan kandang. Peralatan lain yang digunakan pada saat pemeliharaan adalah timbangan dan egg tray. Peralatan yang digunakan saat analisis di laboratorium adalah jangka sorong, tripod micrometer. Bahan yang digunakan yaitu pakan kontrol berupa SP-22 untuk layer produk PT. Shinta Prima Feedmil, tepung tomat dan ampas tahu.

Bahan utama yang digunakan dalam penelitian yaitu pakan komersial, tepung tomat dan ampas tahu. Pakan komersial yang digunakan bermerek dagang SP-22 yang diproduksi oleh PT Shinta Prima Feedmill. Tepung tomat dan ampas tahu merupakan produk rumahan yang didapatkan dari pasar tradisional

\section{Perlakuan}

Perlakuan pada ternak puyuh dilaksanakan saat puyuh berumur 35 minggu. Perlakuan yang dilakukan pada penelitian ini yaitu sebagai berikut: P0 : 100\% Pakan komersial tanpa penambahan tepung tomat dan tepung ampas tahu, P1: 95\% R0 + 2,5\% tepung tomat kering + 2,5\% ampas tahu, P2 : 90\% R0 + 5\% tepung tomat kering $+5 \%$ ampas tahu, P3 : 85\% R0 + $7,5 \%$ tepung tomat dan $7.5 \%$ ampas tahu.

\section{Rancangan Percobaan}

Rancangan yang digunakan dalam penelitian yaitu RAL (rancangan acak lengkap). Terdapat empat perlakuan dengan tiga ulangan yang diuji dalam penelitian. Berikut model matematika yang digunakan dalam penelitian:

$\mathrm{Y}_{i j}=\mu+\mathrm{T}_{i}+\varepsilon_{i j}$

Keterangan:

$\mathrm{Y}_{i j}=$ Nilai pengamatan dari perlakuan $\mathrm{ke}_{-}{ }_{i}$ pada ulangan ke- $j$.

$\mu=$ Nilai tengah umum.

$\mathrm{T}_{i}=$ Pengaruh frekuensi pemberian pakan ke- $i$.

$\varepsilon_{i j}=$ Pengaruh galat percobaan pada frekuensi pemberian pakan $\mathrm{ke}^{-} i$ pada ulangan ke $_{j}$.

\section{Peubah yang Diamati}

Peubah yang diamati pada performa puyuh periode layer yaitu bobot telur,tebal kerabang dan indeks telur. Berikut adalah teknik dalam pengambilan data:

Bobot telur diperoleh dengan cara menimbang telur yang dikoleksi, kemudian dibagi dengan jumlah telur yang dikoleksi. Satuan yang digunakan pada rataan bobot telur yaitu g/butir.

Tebal kerabang diperoleh dengan mengukur tebal menggunakan jangka sorong digital pada bagian ujung runcing, ujung tumpul, dan bagian tengah, kemudian diratakan dalam satuan $\mathrm{mm}$.

Pengamatan diameter telur dapat dikatakan mencari bentuk telur yang ideal (oval) dengan menggunakan jangka sorong.

\section{Analisis Data}

Data yang diperoleh dianalisis dengan sidik ragam (ANOVA) dan jika perlakuan berpengaruh nyata terhadap peubah yang diamati maka analisis dilanjutkan dengan uji lanjut jarak ganda Duncan dengan menggunakan bantuan piranti program SPSS 16 .

\section{Prosedur Pelaksanaan}

Ternak puyuh yang telah berumur 35 hari dipindahkan ke kandang dan sangkar khusus penelitian. Terdapat 13 ekor puyuh/tingkat dari setiap perlakuan dan ulangan.

Puyuh ditempatkan di sangkar sesuai dengan tata letak satuan percobaan. Masa adaptasi puyuh dilakukan selama 7 hari dengan masingmasing perlakuan yang diuji. Pemberian pakan dan air minum pada ternak puyuh selama penelitian yaitu adlibitum (selalu tersedia). Telur yang dijadikan sampel pengamatan dikoleksi seminggu sekali pada pagi hari dan data yang diambil adalah data telur yang dikoleksi dalam 1 minggu masing-masing 3 sampel telur untuk setiap unit perlakuan.

\section{HASIL DAN PEMBAHASAN}

Dalam manajemen produksi ternak puyuh, kualitas eksternal telur puyuh merupakan salah satu aspek penting yang perlu diperhatikan. Ada tiga indikator yang perlu diperhatikan dalam menentukan kualitas eksternal telur puyuh yaitu bobot telur, indeks telur dan tebal kerabang telur. Bobot telur perlu diperhatikan 
karena semakin berat telur maka telur cenderung akan memiliki angka jual yang tinggi dan lebih diminati konsumen, indeks telur yang baik diperlukan untuk grading telur, sedangkan tebal kerabang yang baik akan meminimalisir telur bagian dalam terkontaminasi lingkungan agar isi telur memiliki kualitas yang baik dan tetap terjaga.

Berikut merupakan hasil penelitian eksternal telur putuh selama 4 minggu dan dapat dilihat pada Tabel 1.

Tabel 1 Hasil Kualitas Eksternal Telur Puyuh

\begin{tabular}{|c|c|c|c|}
\hline & $\begin{array}{l}\text { Bobot } \\
(\mathrm{g})\end{array}$ & $\begin{array}{l}\text { Indeks } \\
\text { Telur } \\
(\%) \\
\end{array}$ & $\begin{array}{l}\text { Tebal } \\
\text { Kerabang } \\
(\mathrm{mm})\end{array}$ \\
\hline P0 & $10,82 \pm 0.47$ & $77,86 \pm 0,67$ & $0,197 \pm 0,3$ \\
\hline P1 & $10,57 \pm 0.58$ & $77,97 \pm 0,62$ & $0,206 \pm 0,3$ \\
\hline $\mathrm{P} 2$ & $10,12 \pm 0.40$ & $78,13 \pm 0,67$ & $0,210 \pm 0,3$ \\
\hline P3 & $10,06 \pm 0,30$ & $78,10 \pm 1,27$ & $0,196 \pm 0,3$ \\
\hline
\end{tabular}

\section{Bobot Telur}

Hasil perlakuan dengan pemberian tepung tomat dan ampas tahu sebagai pakan tambahan selama 4 minggu dianalisis keragaman menunjukan perbedaan yang tidak nyata $(\mathrm{P}>0,05)$ pada pertambahan bobot telur puyuh. Tabel 4 menunjukkan bahwa rataan bobot telur burung puyuh secara berurutan mulai dari yang tertinggi hingga terendah adalah sebagai berikut P0 10,8233 $\pm 0,47 \mathrm{~g} /$ butir, P1 10,5767 $\pm 0,58$ g/butir, P2 10,12 $\pm 0,40$ g/butir dan P3 $10,063 \pm 0,30 \mathrm{~g} /$ butir.

Hasil penelitian yang sama juga diperoleh Mansoori et al (2008) dan Salajegheh (2012) melaporkan bahwa penggunaan Dry Tomato Pomace (DTP) pada pakan telur puyuh tidak berpengaruh nyata terhadap bobot telur. Hasil ini diperoleh karena jumlah asam linoleat dan protein kasar pada semua perlakuan sama. Hasil sebaliknya diperoleh Jafari et al (2006) dan Nobakht et al (2007) yang melaporkan bahwa penggunaan DTP pada pakan berpengaruh nyata meningkatkan bobot telur burung puyuh dan hal ini terjadi karena DTP mengandung lysine yang tinggi. Salajegheh et al (2012) menyatakan bahwa hasil yang berbeda pada komposisi kimia DTP khususnya asam amino lysine berpengaruh terhadap bobot telur karena beberapa faktor seperti varietas tomat, bentuk limbah tomat, kondisi tomat selama proses pengolahan, jumlah penggunaan suplementasi tomat dalam pakan, bangsa atau strain unggas, umur ternak unggas dan fase produksi.

Berikut rata-rata bobot telur burung puyuh (Coturnix-coturnix javanica) pada masingmasing perlakuan dapat dilihat pada Gambar 1.

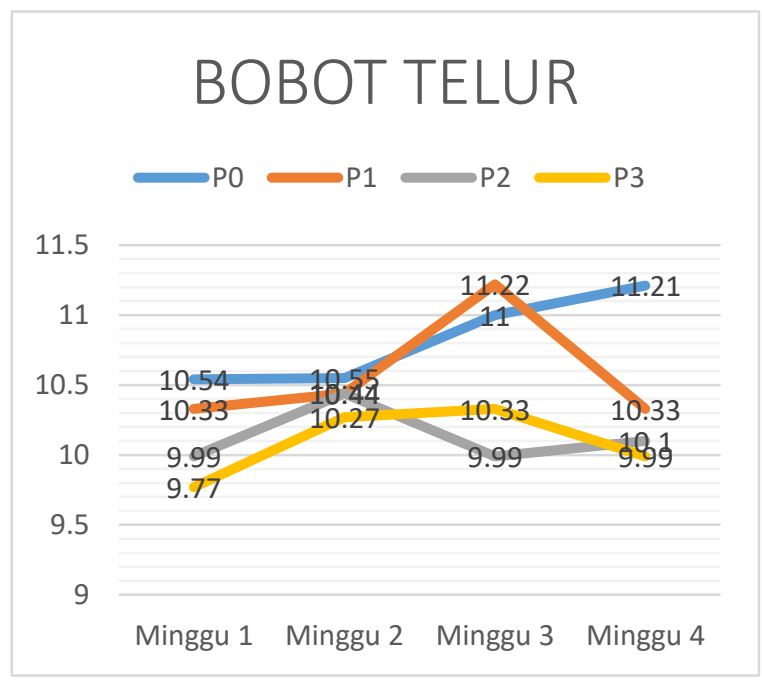

Gambar 1. Rataan bobot telur burung puyuh perminggu.

\section{Tebal Kerabang}

Hasil analisis ragam yang diperoleh memperlihatkan bahwa pemberian tepung tepung tomat dan ampas tahu memberikan pengaruh tidak nyata $(\mathrm{P}>0,05)$ terhadap tebal kerabang telur. Hasil yang diperoleh sama dengan penelitian Mahi et al (2017) yaitu puyuh yang diberi tomat dalam air minum memiliki ketebalan kerabang telur berkisar antara 0,18 sampai 0,21 mm. Namun lebih rendah dari penelitian Prayoga (2018) yaitu burung puyuh yang diberi ransum mengandung kalsium dan fosfor tinggi memiliki ketebalan kerabang telur $0,368 \mathrm{~mm}$.

Menurut Tiwari dan Panda (1978) telur puyuh mempunyai ketebalan kerabang berkisar antara 0.13 sampai dengan $0.21 \mathrm{~mm}$. Menurut Rose (1997) tebal kerabang pada telur puyuh yaitu $0.13 \mathrm{~mm}$. Suprapto et al (2012) menyatakan, mineral yang sangat berperan dalam proses pembentukan kerabang telur adalah kalsium dan fosfor. Kandungan kalsium dan fosfor pada tepung tomat dan ampas tahu 
setelah dikombinasikan hasilnya tidak jauh berbeda dengan kandungan pada pakan komersil sehingga membantu proses absorpsi mineral menjadi lebih baik. Steward dan Abbott (1972) menyatakan bahwa kerabang yang tipis relatif berpori lebih banyak dan besar, sehingga mempercepat turunnya kualitas telur akibat penguapan dan pembusukan lebih cepat, sehingga dapat dikatakan bahwa semakin tebal kerabang maka semakin terjaga kualitas telur agar tidak mudah terjadi pembusukan.

Kebutuhaan puyuh akan kalsium yaitu sebesar 2,5\% sampai dengan 3,5\% sedangkan kebutuhan fosfor yaitu sebesar $0,6 \%$ sampai $1 \%$ (SNI 2006), sehingga dapat dikatakan kalsium dan fosfor yang terdapat di dalam pakan kontrol dan perlakuan sudah memenuhi kebutuhan. Berikut data hasil penelitian mengenai rataan tebal kerabang setiap minggunya pada Gambar 2.

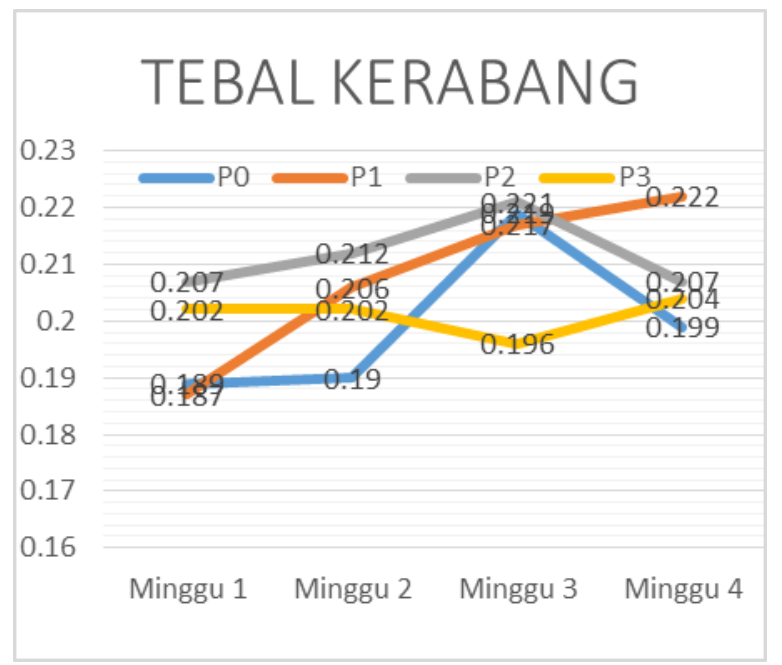

Gambar 2. Rataan tebal kerabang burung puyuh per-minggu.

\section{Indeks Telur}

Data hasil analisis sidik ragam yang diperoleh memperlihatkan bahwa perlakuan (P0, P1, P2, P3) memberikan pengaruh yang tidak nyata $(P>0,05)$ terhadap indeks bentuk telur. Rataan yang diperoleh berkisar antara 77,86-78,13. Indeks bentuk telur yang diperoleh cenderung lebih semi lancip. Indeks telur yang mencerminkan bentuk telur sangat dipengaruhi oleh sifat genetik, bangsa, juga dapat disebabkan oleh proses-proses yang terjadi selama pembentukan telur, terutama pada saat telur melalui magnum dan isthmus (Romanoff 1963). Menurut Yuwanta (2004) indeks bentuk telur berkaitan dengan bobot telur, sedangkan bobot telur dipengaruhi oleh protein. Pakan perlakuan tidak berpengaruh terhadap konsumsi protein dan kecernaan protein sehingga tidak berpengaruh terhadap bobot telur. Hal ini yang menjadikan indeks bentuk telur yang tidak berbeda. Data hasil penelitian mengenai indeks telur dari setiap perlakuan yang diberikan selama penelitian tercantum pada Gambar 3 .

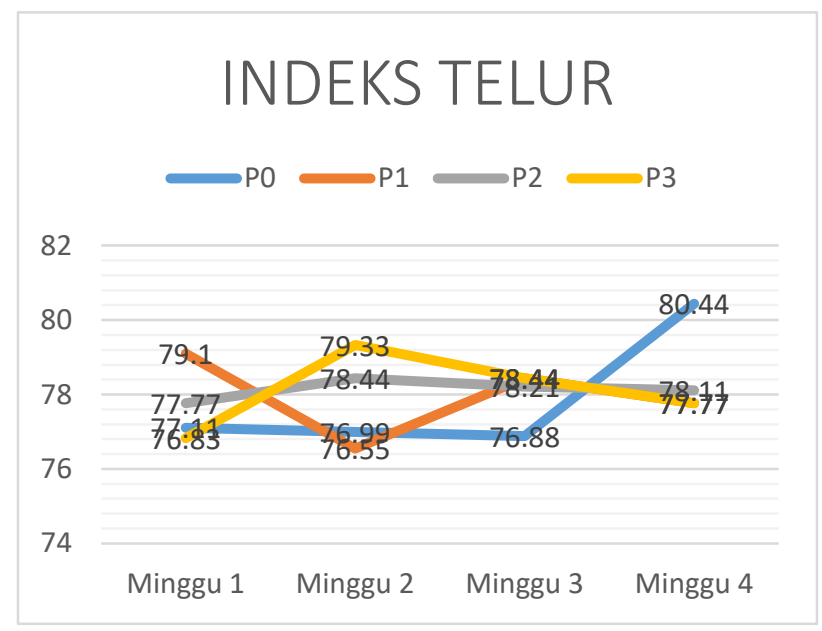

Gambar 3. Rataan indeks telur puyuh peminggu.

\section{KESIMPULAN DAN IMPLIKASI}

\section{Kesimpulan}

Pemberian tepung tomat dan ampas tahu pada pakan burung puyuh tidak mempengaruhi hasil yang nyata pada kualitas eksternal telur burung puyuh (bobot telur, tebal kerabang dan indeks telur).

\section{Implikasi}

Perlu dilakukannya penelitian yang sama akan tetapi dengan peningkatan dosis pada pakan sehingga manfaat yang diberikan akan lebih dirasakan serta waktu penelitian diperpanjang hingga produksi telur puyuh stabil.

\section{DAFTAR PUSTAKA}

Badan Standarisasi Nasional. 2006. Pakan Ayam Ras Pedaging (Broiler Finisher).

Jafari, M. P. Rasoul and V. Bamphidis. 2006. The Use of Dried Tomato Pulp in Diets of Laying Hens. International Journal of Poultry Science 5(7): 618-622. Kanisius.Yogyakarta.

Mansoori, B., Modirsanei, M. and Kiaei, M. M. 2008. Influence of dried tomato pomace as an alternative to wheat bran in maize or wheat based diet, on the performance of laying hens 
and traits of produced eggs. Iranian Journal of Veterinary Research 9(4): 341-346.

Mahi M, Achmanu dan Muharlien. 2012. Pengaruh Bentuk Telur dan Bobot Telur terhadap Jenis Kelamin, Bobot Tetas, dan Lama Tetas Burung Puyuh. Universitas Brawijaya. Malang.

Mappiratu, Nurhaeni dan I. Israwaty. 2010. Pemanfaatan Tomat Afkiran Untuk Produksi Likopen. Media Litbang Silteng 3(1): 64-69.

Nasution, Z. 2007. Pengaruh Suplementasi Mineral dalam Ransum Terhadap Performa dan IOFC Burung Puyuh Umur 0-42 hari. Skripsi. Fakultas Pertanian Universitas Sumatera Utara.

Nobakht, A. and A. R. Safamehr .2007. The Effects on Inclusion Different Levels of Diet Tomato Pomace in Laying Hens Diet on Performace and Plasma and Egg Yolk Cholesterol Contents. Journal of Animal and Veterinary Advances 6 (9): 1101-1106.

Prayoga Nugraha. 2017. Pengaruh pemberian tepung jahe dan tepung kunyit pada ransum terhadap kualitas eksternal telur puyuh. Skripsi. Fakultas Peternakan. Universitas Djuanda

Romanoff A L and Romanoff A J. 1963. The Avian Egg. 2nd Ed. Jhon Wiley and Sons, Inc . New York..

Rose S P. 1997. Principles of Poultry Sciene. CAB International. London.

Salajegheh, M. H., S. Ghazi, R. Mahdavi and 0. Mozafari. 2012. Effects of Different Levels of Dried Tomato Pomace on Performance, Egg Quality and Serum Metabolites of Laying Hens. African Journal of Biotechnology 11(87): 15373-15379. Siregar, Z. 1991. Komposisi Zat-Zat Nutrisi Dalam Pakan Unggas. USU.
Steward G F and Abbott J C. 1972. Marketing Eggs and Poultry. Third Printing. Food and Agricultural Organization (FAO) the United Nation. Rome.

Sumardiono, S., M. Basri, dan R. P. Sihombing. 2008. Analisis Sifat- Sifat Psiko-Kimia Buah Tomat Jenis Tomat Apel, Guna Peningkatan Nilai Fungsi Buah Tomat Sebagai Komoditi Pangan Lokal. Artikel Ilmiah. Jurusan Teknik Fakultas Teknik Universitas Diponegoro.

Suprapto W S, Kismiati dan Suprijatna E. 2012. Pengaruh Penggunaan Tepung Kerabang Telur Ayam Ras Dalam Pakan Burung Puyuh Terhadap Tulang Tibia Dan Tarsus. Animal Agricultural Journal. Vol. 1: 77-85. Tepung Telur, dan Telur Beku

Tiwari K S, Panda B. 1978. Production and Quality Characteristics of Quail Eggs. Indian Journal of Poultry Sci 13 (1): 27-32.

Widodo W. 2002. Bioteknologi Fermentasi Susu. Malang. Pusat Pengembangan Bioteknologi Universitas Muhammadiyah Malang

Yuwanta T. 2004. Dasar Ternak Unggas. Yogyakarta: Kanisius 